\title{
ANTIMICROBIAL-RESISTANT ESCHERICHIA COLI FROM KARST WATERS, SURFACES AND BAT GUANO IN SLOVENIAN CAVES
}

\author{
PROTI PROTIMIKROBNIM UČINKOVINAM ODPORNA \\ ESCHERICHIA COLI V KRAŠKIH VODAH, NA POVRŠINAH \\ IN V GVANU NETOPIRJEV V SLOVENSKIH JAMAH
}

\author{
Sara SKOK ${ }^{1}$, Blaž KOGOVŠEK ${ }^{1}$, Rok TOMAZIN ${ }^{2}$, Samo ŠTURM ${ }^{3}$, Jerneja AMBROŽIČ \\ AVGUŠTIN $^{4} \&$ Janez MULEC ${ }^{1,5^{*}}$
}

\begin{abstract}
UDC 579:551.44(497.4)

Sara Skok, Blaž Kogovšek, Rok Tomazin, Samo Šturm, Jerneja Ambrožič Avguštin \& Janez Mulec: Antimicrobial resistant Escherichia coli from karst waters, surfaces and bat guano in Slovenian caves

Escherichia coli, one of the primary intestinal commensal bacteria in humans and endothermic animals, is commonly considered an indicator of faecal pollution. E. coli strains were isolated from karst rivers under different hydrological conditions, from footpaths in tourist caves and from bat guano. Isolates were tested for phenotypic resistance to ampicillin, chloramphenicol, ciprofloxacin, nalidixic acid, tetracycline and trimethoprim. The highest percentage of antimicrobial resistant $E$. coli was found in karst waters, followed by those from surface swabs and from bat guano. Several isolates from rivers and swabs exhibited multidrug-resistant phenotype. Environmental conditions impact the populations of E. coli; a positive correlation between dissolved oxygen and $E$. coli counts, and a negative correlation between conductivity and E. coli concentrations have been observed for karst rivers. Malenščica (Slovenia), a drinking water resource with an extensive catchment area, contained a relative high percentage of antimicrobial-resistant $E$. coli strains. None of the isolates from bat guano was resistant to ampicillin, chloramphenicol, and tetracycline. Future monitoring of bats should consider a regular follow-up of indicative microbial disease indicators in fresh guano. Regular cleansing of tourist footpaths in caves and disinfection barriers at the cave
\end{abstract}

Izvleček UDK 579:551.44(497.4) Sara Skok, Blaž Kogovšek, Rok Tomazin, Samo Šturm, Jerneja Ambrožič Avguštin \& Janez Mulec: Proti protimikrobnim učinkovinam odporna Escherichia coli v kraških vodah, na površinah in v gvanu netopirjev v slovenskih jamah

Bakterija Escherichia coli, eden najpomembnejših črevesnih komenzalnih mikroorganizmov pri ljudeh in drugih endotermnih živalih, velja za zanesljivega pokazatelja fekalnega onesnaženja. Sevi bakterije $E$. coli so bili izolirani ob različnih hidroloških razmerah iz kraških rek, $s$ turističnih pešpoti $v$ jamah in iz gvana netopirjev. Izolati so bili testirani na izražanje fenotipske odpornosti proti ampicilinu, kloramfenikolu, ciprofloksacinu, nalidiksični kislini, tetraciklinu in trimetoprimu. Največji odstotek E. coli, odpornih proti protimikrobnim učinkovinam, je bil v kraških vodah, sledili so brisi jamskih površin in gvano netopirjev. Pri večjem številu izolatov iz rek in brisov površin je bil izražen fenotip večkratne odpornosti proti testiranim učinkovinam. Okoljske razmere pomembno vplivajo na populacije E. coli; v kraških rekah sta bili opaženi pozitivna korelacija med raztopljenim kisikom in številom E. coli ter negativna korelacija med prevodnostjo in koncentracijo E. coli. Malenščica, vir pitne vode $\mathrm{z}$ velikim prispevnim območjem, je imela razmeroma velik delež sevov E. coli, odpornih proti protimikrobnim učinkovinam. Nobeden izmed izolatov iz gvana netopirjev ni bil odporen proti ampicilinu, kloramfenikolu ali tetraciklinu. Za prihodnji monitoring netopirjev bi bilo smiselno razmisliti o rednem spremljanju prisotnosti mikrobnih bolezenskih indikatorjev v svežem

${ }^{1}$ Research Centre of the Slovenian Academy of Sciences and Arts, Karst Research Institute, Titov trg 2, SI-6230 Postojna, Slovenia, e-mails: blaz.kogovsek@zrc-sazu.si,janez.mulec@zrc-sazu.si,sara.skok@gmail.com

${ }^{2}$ University of Ljubljana, Faculty of Medicine, Institute of Microbiology and Immunology, Zaloška 4, SI-1000 Ljubljana, Slovenia, e-mail: rok.tomazin@mf.uni-lj.si

${ }_{3}^{3}$ Park Škocjanske jame, Slovenija, Škocjan 2, SI-6215 Divača, Slovenia, e-mail: samo.sturm@psj.gov.si

${ }^{4}$ University of Ljubljana, Biotechnical Faculty, Department of Biology, Večna pot 111, SI-1000 Ljubljana, e-mail: jerneja. ambrozic@bf.uni-lj.si

${ }^{5}$ UNESCO Chair on Karst Education, University of Nova Gorica, Glavni trg 8, SI-5271Vipava, Slovenia, e-mail: janez.mulec@zrc-sazu.si

* corresponding author

Received/Prejeto: 06.10.2020

DOI: 10.3986/ac.v49i2-3.9103 
entrances reduce the concentration and transmission of $E$. coli significantly. A future, more detailed, study on characterization of additional E. coli isolates is needed to reveal their pathogeneicity, mechanisms of antibiotic resistance, mobile genetic elements, and gene transfer frequencies to other members of the karst microbiome.

Key words: caves, water, bats, guano, swabs, E. coli, antimicrobial resistance. gvanu. Redno čiščenje turističnih pešpoti v jamah in dezinfekcijska bariera ob vhodu pomembno zmanjšata številčnost in prenos E. coli. V prihodnosti bodo potrebne še nadaljnje in podrobnejše karakterizacije večjega števila izolatov $E$. coli za razumevanje njihove patogenosti, mehanizmov odpornosti proti antibiotikom, mobilnih genetskih elementov in frekvenc genskega prenosa na druge organizme v kraškem mikrobiomu.

Ključne besede: jame, voda, netopirji, gvano, brisi, E. coli, odpornost proti protimikrobnim učinkovinam.

\section{INTRODUCTION}

Local and global ecosystems are affected by various human interventions, in terms of climate change, loss of biodiversity, and land transformation (Vitousek et al. 1997). Interventions are either short-lasting with a transitory impact, or permanent, which commonly include physical changes of the habitat (Vitousek et al. 1997), and introduction of allochthonous material, including biota (Mösslacher et al. 2001; Vitousek et al. 1997). Consequently, the autochthonous communities can be affected and changed. Evaluation of human impact is an important step in following the dynamics and trends within the changing ecosystems to foresee the need for protection measures. Karst ecosystems are also subjected to such changes (Notenboom et al. 1994). For example, karst groundwater environments are highly vulnerable to agricultural, urban or industrial impacts from both pointsource and dispersed pollution (Kačaroğlu 1999). In many ways karst caves are an excellent model to observe and quantify different external impacts, for example on groundwater quality or cave-adapted biota in show caves. Some caves host bats - migratory animals and top predators. Because of their sensitivity to changes in land use, agriculture and habitat fragmentation, bats are particularly good indicators of changes affecting wildlife and surrounding areas (Jones et al. 2009).

Complete insight into ecosystem changes is obtained only by a simultaneous follow-up monitoring of physico-chemical parameters and the biota, including the microbiota. Escherichia coli, a Gram-negative bacterium from the Enterobacteriaceae family, is primarily a member of the gut microbiota in humans and other endothermic animals, and is therefore widely regarded as an indicator for faecal pollution, when it is isolated from other environments (Odonkor \& Ampofo 2013; Jang et al. 2017). In the human gut, E. coli is regarded as a commensal microbe. However, due to the extreme plasticity of its genome, strains "equipped" with virulence factor genes can cause several intestinal and extraintestinal infections. Among them, most frequent are urinary tract infections and bloodstream infections in the European Union/European Economic Area, and they have both community and healthcare origins. These infections are usually treated with antimicrobials. The extensive use of antimicrobial agents in human and veterinary medicine and in agriculture, has led to a dramatic increase in the number of antimicrobial resistant bacteria (ARB) and antimicrobial resistance genes (ARG) encoded predominantly on mobile genetic elements (MGE). Thus, the "circulation" of resistant, commensal and pathogenic E. coli between the clinical settlement and natural ecosystems enables the transfer of antimicrobial resistant (AMR) E. coli and ARG from human impacted areas (clinics, animal farms, wastewater treatment plants, ...) to pristine natural habitats, e.g., underground karst water, and their biota. From this point of view, it is important to detect and monitor the number of AMR-E. coli, their resistance profiles and putative MGEs, as well as possible entry points into such environments (Zhang et al. 2013).

Recently it has been reported that the most important and/or prevalent detected resistance in E. coli strains from Europe is against aminopenicillins, fluoroquinolones, third generation cephalosporins and aminoglycosides. Currently, strains resistant against carbapenems remain rare in Europe (European Centre for Disease Prevention and Control 2018). In Slovenia in 2017, when the majority of samples for this study were collected, the highest proportion of resistant E. coli clinical isolates was detected in the case of aminopenicillins, where it reached $51.6 \%$, followed by fluoroquinolones and third generation cephalosporins with proportions of $24.9 \%$ and 12.5 $\%$ respectively. Combined resistance against third generation cephalosporins, fluoroquinolones and aminoglycosides was observed in $6.3 \%$ of $E$. coli clinical isolates. Carbapenem-resistance was, however, not detected in the E. coli population surveyed in 2017 (European Centre for Disease Prevention and Control 2017, 2018).

During the present study, flowing surface waters and groundwaters, solid surfaces impacted by organized tours in show caves, and bat guano were screened for E. coli, and compared according to the phenotypic resistance of $E$. coli to selected antimicrobials, i.e., ampicillin (AMP), chloramphenicol (CHL), ciprofloxacin 
(CIP), nalidixic acid (NAL), tetracycline (TET) and trimethoprim (TMP). These antimicrobials were selected because they were already reported from comparable environments (Reinthaler et al. 2003; Amaya et al. 2012). It is important to stress that highly karstifed zones can enable more intermicrobial contacts and potential gene transfer into the natural resistome via water flow, air streaming and migratory animals and humans.

\section{MATERIAL AND METHODS}

\section{DESCRIPTION OF SITES AND SAMPLES}

\section{WATER SAMPLES}

Water samples were collected from five karst rivers (Črni potok, Malenščica, Pivka, Rak, Unica, Fig. 1). These rivers are part of the nearly $800 \mathrm{~km}^{2}$ catchment area of the Malenščica and Unica springs. The Pivka River (and Črni potok to a minor extent) is the main allogenic recharge for the Postojnski jamski sistem (Postojna Cave System, $45^{\circ} 46^{\prime} 57^{\prime \prime} \mathrm{N}, 14^{\circ} 12^{\prime} 13^{\prime \prime} \mathrm{E}, 529 \mathrm{~m}$ a.s.l., total length $24 \mathrm{~km}$ ), which comprises several caves (Postojnska jama, Otoška jama, Magdalena jama, Pivka jama, Črna jama), where the underground Pivka River is accessible and collects isotopically different waters from the aquifer. The underground Pivka River is impacted by human activities within the surrounding area, as is indicated by occasionally elevated concentrations of sulphates, chlorides, and organic and faecal pollutants (Mulec et al. 2019). In the underground it continues towards Planinska jama, where it converges with the Rak cave stream. Downstream from the underground confluence, the river emerges as the Unica $\left(45^{\circ} 49^{\prime} 13^{\prime \prime} \mathrm{N}, 14^{\circ} 14^{\prime} 45^{\prime \prime} \mathrm{E}, 453 \mathrm{~m}\right.$ a.s.l.). The Malenščica spring $\left(45^{\circ} 49^{\prime} 20^{\prime \prime} \mathrm{N}, 14^{\circ} 15^{\prime} 19^{\prime \prime} \mathrm{E}\right)$ is exploited as a drinking water source for 21,000 inhabitants of the surrounding area (Petrič 2010).

Sampling locations were selected upstream of the river sinks into the karst underground, along the underground water courses, and at the springs (see Fig. 1B for sampling sites). On-site measurements of temperature (T), electric conductivity (EC), $\mathrm{pH}$ and dissolved oxygen (DO)

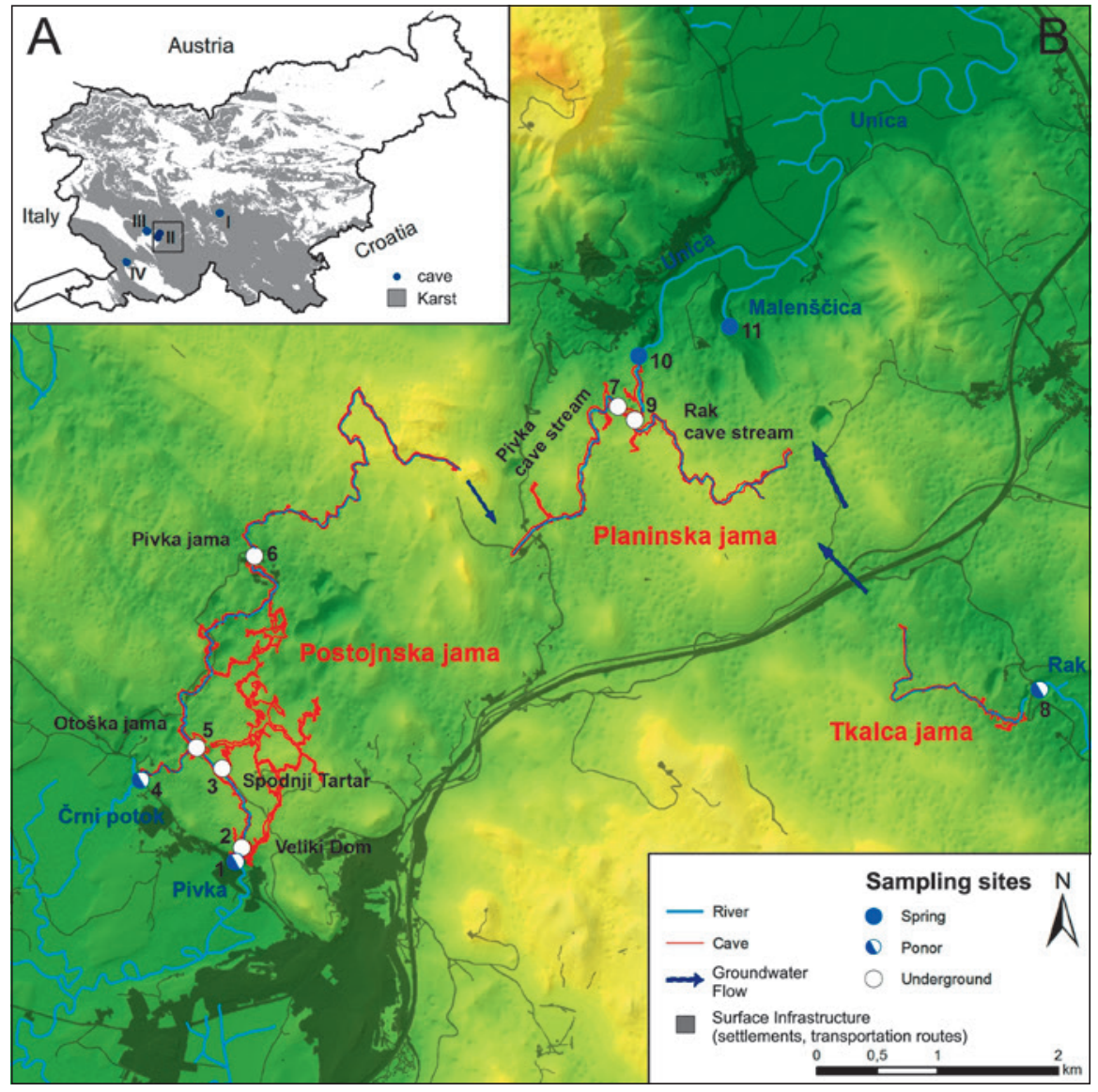

Fig. 1: Study sites: A - location of investigated caves (I - Županova jama, II - Postojnska jama and Planinska jama, III - Predjama, IV - Škocjanske jame); B - map of the area with water sampling sites (Map based on ARSO 2019; Cave Cadastre 2019). 
were performed using a Multi-parameter portable meter (WTW Multiline Multi 3620 IDS). After sampling, samples were transferred in a cool-box to the laboratory, where one millilitre of each specimen was placed directly onto microbiological media. The total ATP concentration of each sample served to estimate its total microbial biomass.

Samples were collected under different hydrological conditions during 2017; from Črni potok in June, July, August and November, from Malenščica in September, from the Pivka in May, July, August, September, October and November, from the Rak in September, and from the Unica in September, October and November.

\section{SURFACE SWAB SAMPLES}

Swab samples from tourist footpaths were collected from four caves. In Postojnska jama, 780,000 tourists visited 5.3 $\mathrm{km}$ of the underground galleries in 2017. The surfaces of tourist footpaths are cleaned monthly with water jets. A disinfection barrier is installed at the entrance to the cave (Appendix 2). Predjama (Predjama Cave, $45^{\circ} 48^{\prime} 56^{\prime \prime} \mathrm{N}$, $14^{\circ} 7^{\prime} 35^{\prime \prime} \mathrm{E}, 491 \mathrm{~m}$ a.s.l.) is explored in the total length of approximately $17 \mathrm{~km} .0 .7 \mathrm{~km}$ is visited annually by approximately 7,000 tourists. The first part of the cave serves as hibernaculum and swarming site for at least 13 bat species (Barbastella barbastellus, Eptesicus serotinus, Miniopterus schreibersii, Myotis capaccinii, M. daubentonii, M. oxygnathus, M. myotis, M. nattereri, Nyctalus noctula, Pipistrellus pipistrellus, P. pygmaeus, Rhinolophus ferrumequinum, $R$. hipposideros). M. schreibersii presents almost $2 / 3$ of individuals, with approximately 1,200 to 1,500 hibernating bats (Presetnik et al. 2009). Bat droppings have accumulated in the form of heaps, and they are also scattered along the tourist footpath, from where the samples were collected. Škocjanske jame (Škocjan Caves, $45^{\circ} 39^{\prime} 54^{\prime \prime} \mathrm{N}, 13^{\circ} 59^{\prime} 38^{\prime \prime} \mathrm{E}$, $317 \mathrm{~m}$ a.s.l., total length $6.2 \mathrm{~km}$ ) are on the UNESCO World Heritage List and recognized as an underground karst wetland under the Ramsar Wetland Classification System. A 2.6 $\mathrm{km}$ section of the cave that is open to visitors throughout the year attracted 185,000 visitors in 2017. Nine bat species were documented in the cave (Barbastella barbastellus, Miniopterus schreibersii, Myotis blythii, M. capaciinii, M. myotis, Pipistrellus pipistrellus, Plecotus macrobullaris, Rhinolophus euryale, $R$. ferrumequinum, $R$. hipposideros). The predominant species, exceeding 8,000 individuals during the winter hibernation, is M. schreibersii (Presetnik et al. 2017). Consequently, parts of the tourist footpath are covered with bat droppings. Tourist footpaths are cleaned using water jets once per year in September. Županova jama (Županova Cave, $45^{\circ} 54^{\prime} 47^{\prime \prime} \mathrm{N}, 14^{\circ} 38^{\prime} 17^{\prime \prime} \mathrm{E}, 468 \mathrm{~m}$ a.s.l.) is a smaller tourist cave $(0.71 \mathrm{~km}$ total length, with $0.61 \mathrm{~km}$ equipped for tourist access) visited by 5,000 tourists per year.

On the tourist footpaths sampling sites for swabs were delimited with a template for bioburden control $(5 \times 4 \mathrm{~cm}$, Copan Diagnostics Inc.) and sampled with a FLOQSwabsTM (Copan). Swabs were transferred into one millilitre of saline solution. In the laboratory, samples were vortexed vigorously, and the liquid was collected in a separate tube. Additionally, each swab was centrifuged for 10 minutes at 4,000 RPM in its original tube to release any remaining liquid and associated microbes. Subsequently the liquid was used for inoculation of microbiological plates and estimation of the total ATP.

Swabs were collected from Postojnska jama, Predjama and Županova jama in November 2017 and in Škocjanske jame in September 2017.

\section{GUANO SAMPLES}

Guano scattered on the cave floor was sampled in Predjama in June 2018 and Škocjanske jame in April 2018. In addition, fresh guano was collected under roosting bat colonies in Škocjanske jame (the section named Schmidlova dvorana and Rudolfova dvorana, 100 and $200 \mathrm{~m}$ from the cave entrance respectively), in August-September 2018. Sterilized aluminium foil sheets were placed along the tourist footpath (which was not in use during guano collection) under bat colonies, and samples were collected after 7, 18 and 30 days of accumulation (Appendix 1). Based on the results of field observations, the fresh guano probably belonged to a mixed population of several hundred individuals of Miniopterus schreibersii, Myotis myotis, Myotis blythii and Myotis capaciinii.

In the laboratory, each guano sample was resuspended in saline solution $(1: 10 \mathrm{w} / \mathrm{v})$, serially diluted (up to $10^{-3}$ ), and plated onto $E$. coli selection medium.

\section{MICROBIAL BIOMASS ESTIMATION, ISOLATION AND IDENTIFICATION OF E. COLI}

The ATP content in samples was estimated using AquaSnap Total testing instruments (Hygiena, USA) and expressed in RLU - Relative Light Units (where $1 \mathrm{RLU}$ equates to $1 \mathrm{fmol}$ of ATP) per millilitre (RLU / $\mathrm{ml}$ ) or swabbed surface (RLU $/ 20 \mathrm{~cm}^{2}$ ).
Ready-to-use microbiological media Compact Dry (Nissui Pharmaceutical, Japan) were used to estimate the concentration of heterotrophic aerobic bacteria (Compact Dry TC), coliforms and E. coli (Compact Dry EC) and enterococci (Compact Dry ETC). One set 
of TC plates was cultivated for 48 hours at $37^{\circ} \mathrm{C}$, and another set for 7 days at $20^{\circ} \mathrm{C}$. Numbers of bacteria were expressed as Colony-Forming Units (CFU) per millilitre for water samples or CFU per $20 \mathrm{~cm}^{2}$ for surface swabs.

Coloured colonies indicative for E. coli on Compact Dry EC plates were further purified on CCA agar (Coliforms Chromogenic Agar, Conda Pronadisa, Spain) and subjected to identification by MALDI-TOF MS (MatrixAssisted Laser Desorption/Ionization Time-Of-Flight Mass Spectrometry). Pure isolates from CCA plates were subsequently inoculated on $5.0 \%$ defibrinated sheepblood agar (BA) and incubated at $36 \pm 1{ }^{\circ} \mathrm{C}$ for 24 to 48 hours. BA was prepared at the Institute of Microbiology and Immunology, Faculty of Medicine, University of Ljubljana, and contained $15 \mathrm{~g}$ agar (Sigma-Aldrich), brainheart infusion broth (Becton Dickinson, Sparks, MD, USA), and $50 \mathrm{ml}$ defibrinated reoxygenated sheep blood (Bio Gnost, Zagreb, Croatia) per $1000 \mathrm{ml}$. Bacterial isolates on the BA were subjected to identification using MALDI-TOF MS with an on-target formic acid extraction technique. A 24 to 48 hours-old single colony was smeared onto the MALDI steel plate and overlain with 1 $\mu \mathrm{l}$ of $98 \%$ formic acid. After drying, the sample was overlain with $1 \mu \mathrm{l}$ of photo-absrobent, $a$-cyano-4-hydroxycinnamic acid matrix solution in $50 \%$ acetonitrile- 2.5 $\%$ trifluoroacetic acid (Bruker Daltonik, Germany) and left to dry before subsequent analysis with a linear-mode microflex LT/SH MALDI-TOF MS system, Biotyper RTC software version 3.1 (Bruker Daltonik). The Bruker bacterial test standard (Bruker Daltonik) was used for calibration according to the manufacturer's instructions. Quality of identification was assessed using the manufacturer's score value. A score of $\geq 2.000$ indicated reliable species level identification, a score of 1.700 to 1.999 indicated reliable identification to the genus level, and a score of $<1.700$ was interpreted as unreliable identification.

Identified E. coli isolates were designated (EC) and deposited at the Ex Culture Collection at the Department of Biology, Biotechnical Faculty, University of Ljubljana (Infrastructural Centre Mycosmo, MRIC UL, Slovenia).

\section{ANTIMICROBIAL SUSCEPTIBILITY TESTING}

Isolates from overnight incubation (minimum requirement - belonging to genus Escherichia defined by MALDI-TOF MS Score value $>1.700$ ), were tested for antibiotic resistance against AMP $(0.016-256 \mu \mathrm{g} / \mathrm{ml}), \mathrm{CHL}$ $(0.016-256 \mu \mathrm{g} / \mathrm{ml})$, CIP $(0.002-32 \mu \mathrm{g} / \mathrm{ml})$, NAL $(0.016-$ $256 \mu \mathrm{g} / \mathrm{ml})$, TET $(0.016-256 \mu \mathrm{g} / \mathrm{ml})$ and TMP $(0.002-32$ $\mu \mathrm{g} / \mathrm{ml})$. Susceptibility testing was carried out using the gradient diffusion method on unsupplemented MuellerHinton agar (MHA, bioMérieux SA, France). The inoculum was prepared by suspending pure overnight cultures in saline solution, approximately corresponding to $1-2 \times 10^{8} \mathrm{CFU} / \mathrm{ml}$. The inoculum was spread evenly over the entire surface of the MHA plates using a sterile cotton swab. E-test gradient strips (bioMérieux SA, France, for AMP, CHL, CIP, NAL, TET, and Bioanalyse, Turkey, for TMP) were applied on the agar surface within 15 minutes of inoculation of the plates. After 24 hours of ambient air incubation at $36 \pm 1^{\circ} \mathrm{C}$, MICs (Minimum Inhibitory Concentrations) were determined visually according to the manufacturer's instructions (bioMérieux, Bioanalyse). The results were interpreted according to the EUCAST (European Committee on Antimicrobial Susceptibility Testing) epidemiological cutoff values (ECOFF) for $E$. coli: AMP at $8 \mathrm{mg} / \mathrm{l}, \mathrm{CHL}$ at $16 \mathrm{mg} / \mathrm{l}, \mathrm{CIP}$ at $0.064 \mathrm{mg} / \mathrm{l}$, NAL at $16 \mathrm{mg} / \mathrm{l}$, TET at $8 \mathrm{mg} / \mathrm{l}$ and TMP at $2 \mathrm{mg} / \mathrm{l}$ (EUCAST 2019).

\section{STATISTICAL ANALYSES}

Statistical analyses were performed using Daniel's XL Toolbox, an open-source add-in for Microsoft Excel (Version 6.60, licensed under the Apache License, Version 2.0, Daniel Kraus, Würzburg, Germany).

\section{RESULTS}

\section{IDENTIFICATION AND ENVIRONMENTAL CONDITIONS}

Samples that tested positive for the presence of E. coli on Compact Dry EC selection medium were further processed and analysed. Altogether 211 colonies were subjected to identification by MALDI-TOF MS. From these, 185 isolates were E. coli (highly probable species identification -100 , secure genus identification -77 , probable genus identification -8 ). The remaining isolates belonged to genera from the Enterobacteriaceae family (Enterobacter, Hafnia, Morganella, Proteus, Providencia, Serratia and Yersinia). Subsequently, 168 E. coli isolates were selected in the final dataset for antimicrobial susceptibility testing.

E. coli strains were retrieved from waters under different environmental conditions (Tab. 1). Statistically significant positive correlations were observed between DO and concentrations of E. coli $(\mathrm{r}=0.325, \mathrm{p}=0.008)$, 
enterococci $(r=0.372, p=0.002)$ and total heterotrophic bacteria grown at $20^{\circ} \mathrm{C}(\mathrm{r}=0.342, \mathrm{p}=0.004)$. Negative correlations have been between EC and concentrations of $E$. coli $(r=-0.446, p=0.000)$, enterococci $(r=-0.372$, $\mathrm{p}=0.001)$ and total heterotrophic bacteria grown at 20 ${ }^{\circ} \mathrm{C}(\mathrm{r}=-0.265, \mathrm{p}=0.024)$.

Whereas the ATP concentration values are indicative of abundant microbial biomass in all rivers, E. coli represented only a small proportion within the microbial communities. A comparatively high concentration of $E$. coli, relative to total microbial biomass, was detected in the Pivka River (sampling sites nos. 1 and 2, Fig. 1B) and even in water samples from the Malenščica spring (sampling site No. 11, Fig. 1B), a drinking-water source (Tab. 3).

Surfaces of the tourist footpaths in caves varied in their microbiological load. ATP biomass estimator showed the lowest bioburden on tourist footpaths in Županova jama and relative uniform concentrations in Škocjanske jame and Predjama, both inhabitated by bats. Among the sites tested the cultivable microbial biomass was the lowest in Postojnska jama. This can be attributed to effective cleaning of the tourist footpaths one week before the surfaces were sampled. The highest number of $E$. coli retrieved during the study was in Škocjanske jame, with more than $500 \mathrm{CFU} / 20 \mathrm{~cm}^{2}$ (Tab. 2).

In Predjama and Škocjanske jame, respectively 7 and 32 E. coli strains were isolated from non-fresh guano. Additionally, 34 strains were isolated from fresh guano sampled in Škocjanske jame.

\section{ANTIBIOTIC SUSCEPTIBILITY TESTING}

The MICs obtained were interpreted according to ECOFF, which divides the bacterial population into:

- in vitro sensitive wild types (WT) - if they expressed MIC $\leq$ ECOFF they do not have phenotypically detectable acquired resistance mechanisms to a specified antimicrobial agent, and thus represent a "normal" population

- in vitro resistant/less susceptible non-wild types

Tab. 1: Ranges of environmetal parameters of the studied rivers.

\begin{tabular}{|l|ccccc|}
\hline \multirow{2}{*}{ Parameter } & \multicolumn{5}{|c|}{ River } \\
\cline { 2 - 6 } & Črni potok & Malenščica & Pivka & Rak & Unica \\
\hline $\mathrm{T}\left({ }^{\circ} \mathrm{C}\right)$ & 3.8 & $8.8-10.2$ & $4.9-15.1$ & $9.0-11.6$ & $6.9-11.1$ \\
$\mathrm{EC}(\mu \mathrm{S} / \mathrm{cm})$ & 103 & $382-393$ & $302-394$ & $358-425$ & $332-452$ \\
$\mathrm{pH}$ & 7.00 & $7.48-7.59$ & $7.64-8.29$ & $7.50-8.22$ & $7.47-8.02$ \\
$\mathrm{DO}(\mathrm{mg} / \mathrm{l})$ & 9.28 & $9.10-10.06$ & $6.22-13.92$ & $8.23-11.68$ & $10.47-12.90$ \\
$\mathrm{DO}(\%)$ & 75.5 & $83.6-94.3$ & $66.4-117.0$ & $80.4-108.7$ & $100.2-111.0$ \\
& & & & & \\
ATP $(\mathrm{RLU})$ & 80 & $6-27$ & $88-439$ & $9-128$ & $9-344$ \\
$\mathrm{TC}-20^{\circ} \mathrm{C}(\mathrm{CFU} / \mathrm{ml})$ & 181 & $165-511$ & $530-1850$ & $249-1081$ & $121-1300$ \\
$\mathrm{TC}-37{ }^{\circ} \mathrm{C}(\mathrm{CFU} / \mathrm{ml})$ & 6 & $32-160$ & $30-1200$ & $44-411$ & $10-484$ \\
E. coli (CFU/ml) & 5 & $1-9$ & $1-54$ & $1-23$ & $1-24$ \\
Coliforms (CFU/ml) & 6 & $9-40$ & $2-308$ & $18-205$ & $3-228$ \\
ETC $(\mathrm{CFU} / \mathrm{ml})$ & 2 & $0-4$ & $0-84$ & $0-22$ & $0-36$ \\
\hline
\end{tabular}

TC - heterotrophic aerobic bacteria; ETC - enterococci

Tab. 2: Value ranges of bacterial indicators on swabbed surfaces.

\begin{tabular}{|l|cccc|}
\hline \multirow{2}{*}{ Parameter } & \multicolumn{4}{|c|}{ Cave } \\
\cline { 2 - 5 } & Postojnska jama & Predjama & Škocjanske jame & Županova jama \\
\hline ATP $\left(\mathrm{RLU} / 20 \mathrm{~cm}^{2}\right)$ & $3,804-27,036$ & $2,784-17,952$ & $2,776-22,240$ & $1,480-24,304$ \\
TC-37 ${ }^{\circ} \mathrm{C}\left(\mathrm{CFU} / 20 \mathrm{~cm}^{2}\right)$ & 5,067 & $11,400-41,019$ & $9,800-170,667$ & $17,400-35,600$ \\
Coliforms $\left(\mathrm{CFU} / 20 \mathrm{~cm}^{2}\right)$ & 324 & $92-3,480$ & $548-1,532$ & $812-3,400$ \\
E. coli $\left(\mathrm{CFU} / 20 \mathrm{~cm}^{2}\right)$ & 28 & $56-228$ & $52-580$ & $20-68$ \\
\hline
\end{tabular}

TC - heterotrophic aerobic bacteria 
$(\mathrm{NWT})$ - in cases of MIC > ECOFF, when they have phenotypically detectable acquired resistance mechanisms.

The division of isolates into WT and NWT does not consider clinical and pharmacological (pharmacokinetic and pharmacodynamic) factors and is therefore not related to the patient (human, animal) and antimicrobial therapy regimen (EUCAST 2017). For most of the antimicrobial drugs tested (AMP, CHL, TET, TMP), clinical breakpoints (CBS) have been set for interpreting the susceptibility-testing results for E. coli, and can therefore be classified as susceptible, susceptible-increased exposure, or resistant, according to obtained MICs. But because these CBS values are set only for infections caused by $E$. coli in human patients, the results have been interpreted only on the basis of their ECOFF, because this is not patient-species dependent.

The highest percentages of NWT E. coli strains were found in samples collected from rivers $(12.5 \%$ for CIP, NAL and TMP, $9.7 \%$ for TET, $8.3 \%$ for AMP, $4.2 \%$ for $\mathrm{CHL}$ ), followed by those from contact surface isolates. $E$. coli isolates derived from guano samples expressed low percentages of in vitro phenotypic resistance. None of the isolates was resistant to AMP, CHL and TET. E. coli isolated from fresh guano expressed phenotypic resistance only to TMP (1.4 \%, Fig. 2).

Comparison of the river samples showed that isolates from Malenščica contained the highest percentage of NWT isolates $(\mathrm{n}=12,58.3 \%)$, followed by those from the Unica $(\mathrm{n}=12,33.3 \%)$, the Pivka $(\mathrm{n}=28,32.1 \%)$ and the Rak $(\mathrm{n}=18,16.7 \%)$. Neither of the two isolates from Črni potok expressed in vitro antimicrobial resistence. The highest percentage of NWT E. coli isolates from surface swab samples was detected among the Škocjanske jame samples $(\mathrm{n}=18,33.3 \%)$, followed by those from Županova jama ( $=5,20 \%)$, and then those from Predjama $(n=15,6.7 \%)$. The single isolate from Postojnska jama expressed in vitro resistence to TMP.

Several isolates from rivers and surfaces were multidrug resistant, and some of them expressed no in vitro inhibition with MICs exceeding the highest tested value designated on E-test gradient strips. A strain from the ponor of the Pivka into Postojnska jama was resistant to all tested antimicrobials (Tab. 3; Tab. 4). Guano isolates were less resistant than those from both the water and surface isolates (Tab. 5).

The highest percentage of $E$. coli in the microbial community (12.2-59.2\%) and the highest percentage of NWT E. coli (33.3 \%) were detected in swabs from Škocjanske jame, followed by swabs from Županova jama $(20.0 \%)$ and those from Predjama (6.7 \%). Altogether, ten surface swabs were sampled in Postojnska jama, but only one of them was positive for E. coli, despite a high total biomass in the sample (Tab. 4).

Compared to the E. coli isolated from river water and swabs, the isolates from guano expressed the lowest in vitro resistance to the selected antimicrobials $(\mathrm{n}=55$, $9.0 \%)$.

The MIC ranges, $\mathrm{MIC}_{50}, \mathrm{MIC}_{90}$ and mean MICs of six antibacterial drugs are presented in Tab. 6, and MIC distributions are shown in Fig. 3. The overall MIC ranges for each of six antimicrobial drugs were $0.5-256 \mu \mathrm{g} /$ $\mathrm{ml}$ for AMP, $4-256 \mu \mathrm{g} / \mathrm{ml}$ for CHL, $0.008-32 \mu \mathrm{g} / \mathrm{ml}$ for CIP, $1-256 \mu \mathrm{g} / \mathrm{ml}$ for NAL, $0.75-256 \mu \mathrm{g} / \mathrm{ml}$ for TET and $0.125-32 \mu \mathrm{g} / \mathrm{ml}$ for TMP. NAL and AMP had the highest mean MIC of $17.6 \mu \mathrm{g} / \mathrm{ml}$ and $15.9 \mu \mathrm{g} / \mathrm{ml}$, respectively. The lowest mean MIC was for CIP with $0.221 \mu \mathrm{g} / \mathrm{ml}$.

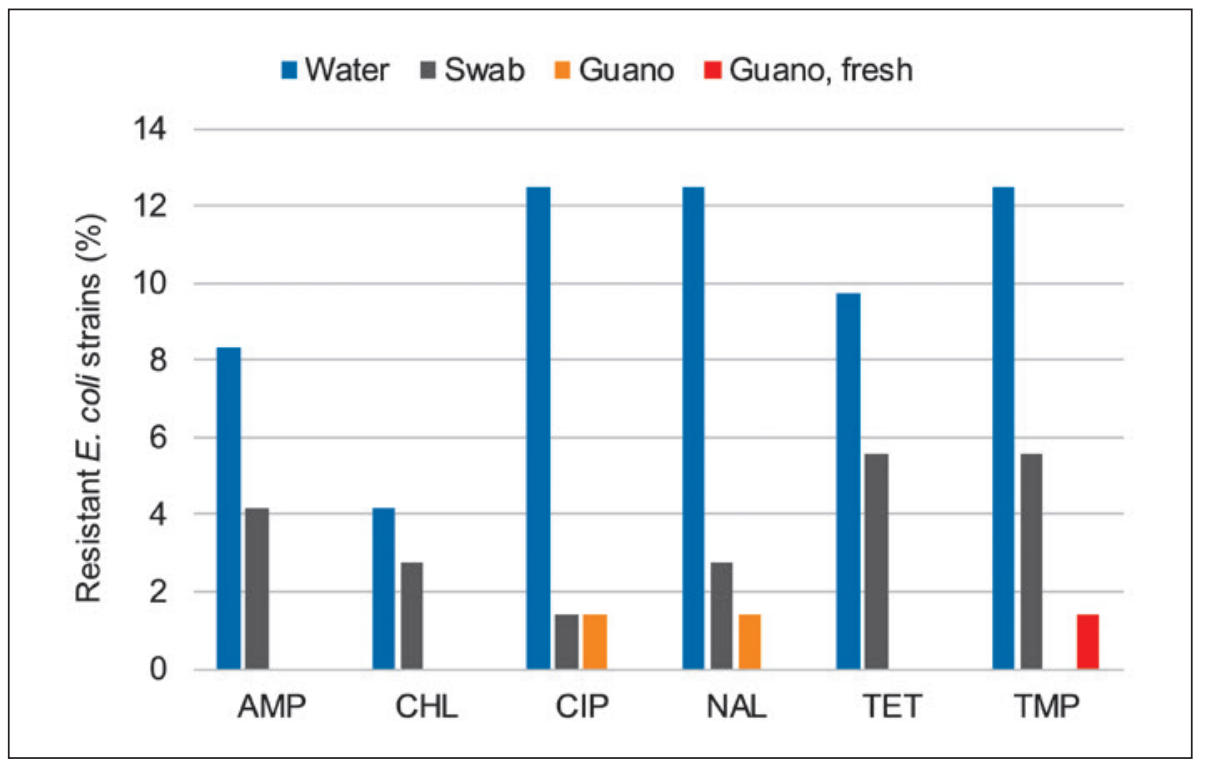

Fig. 2: Percentage of NWT E. coli strains, isolated from karst water, surfaces and guano, resistant to $A M P, C H L, C I P, N A L, T E T$ and TMP. 
Tab. 3: Antimicrobial resistance phenotype and percentage of E. coli isolates according to total biomass and cultivable bacterial indicators from water samples (see Fig. 1 B for sampling sites).

\begin{tabular}{|c|c|c|c|c|c|c|}
\hline Strain & River / site no. & $\begin{array}{l}\text { Antimicrobial resistance } \\
\text { phenotype }\end{array}$ & $\underset{\mathrm{ml}^{\#}}{\operatorname{ATP}(\mathrm{RLU}) / \mathrm{CFU} /}$ & $\begin{array}{l}\text { E. coli } \\
(\%)^{*}\end{array}$ & $\begin{array}{l}\text { E. coli } \\
(\%)^{* *}\end{array}$ & $\begin{array}{l}\text { E. coli } \\
(\%)^{* * *}\end{array}$ \\
\hline EC40 & Malenščica / 11 & AMP & $27 / 10^{5}$ & 0.0090 & 2.4 & 7.7 \\
\hline EC42 & Malenščica / 11 & AMP & $27 / 10^{5}$ & 0.0090 & 2.4 & 7.7 \\
\hline EC45 & Malenščica / 11 & CIP, NAL & $26 / 10^{5}$ & 0.0050 & 1.0 & 3.1 \\
\hline EC55 & Malenščica / 11 & NAL, TMP & $27 / 10^{5}$ & 0.0090 & 2.4 & 7.7 \\
\hline EC66 & Malenščica / 11 & CIP, NAL, TMP & $26 / 10^{5}$ & 0.0050 & 1.0 & 3.1 \\
\hline EC67 & Malenščica / 11 & CIP, NAL & $26 / 10^{5}$ & 0.0050 & 1.0 & 3.1 \\
\hline EC68 & Malenščica / 11 & CIP, NAL & $26 / 10^{5}$ & 0.0050 & 1.0 & 3.1 \\
\hline EC61 & Pivka / 1 & TET, TMP & $439 / 10^{6}$ & 0.0035 & 4.0 & 6.1 \\
\hline EC126 & Pivka / 1 & $\mathrm{CHL}$ & $207 / 10^{6}$ & 0.0054 & 5.0 & 14.4 \\
\hline EC127 & Pivka / 1 & $\begin{array}{l}\text { AMP, CHL, CIP, NAL, TET, } \\
\text { TMP }\end{array}$ & $207 / 10^{6}$ & 0.0054 & 5.0 & 14.4 \\
\hline EC130 & Pivka / 1 & TET, TMP & $207 / 10^{6}$ & 0.0054 & 5.0 & 14.4 \\
\hline EC95 & Pivka / 2 & AMP, CIP, NAL, TET, TMP & $135 / 10^{6}$ & 0.0006 & 0.8 & 20.0 \\
\hline EC119 & Pivka / 2 & NAL & $129 / 10^{6}$ & 0.0043 & 3.6 & 11.3 \\
\hline EC120 & Pivka / 5 & NAL & $206 / 10^{6}$ & 0.0043 & 3.3 & 10.8 \\
\hline EC121 & Pivka / 5 & TMP & $206 / 10^{6}$ & 0.0043 & 3.3 & 10.8 \\
\hline EC44 & Pivka / 7 & AMP, TET, TMP & $363 / 10^{6}$ & 0.0005 & 0.7 & 1.0 \\
\hline EC38 & Rak / 9 & CIP & $25 / 10^{5}$ & 0.0020 & 0.5 & 1.9 \\
\hline EC39 & Rak / 9 & $\mathrm{CIP}$ & $25 / 10^{5}$ & 0.0020 & 0.5 & 1.9 \\
\hline EC65 & Rak / 9 & TMP & $12 / 10^{4}$ & 0.0100 & 0.3 & 0.8 \\
\hline EC27 & Unica / 10 & $\mathrm{CIP}$ & $146 / 10^{6}$ & 0.0022 & 2.4 & 4.8 \\
\hline EC87 & Unica / 10 & AMP, TET & $344 / 10^{6}$ & 0.0005 & 0.6 & 1.0 \\
\hline EC124 & Unica / 10 & $\mathrm{CHL}$ & $174 / 10^{6}$ & 0.0024 & 1.8 & 13.1 \\
\hline EC125 & Unica / 10 & TET & $174 / 10^{6}$ & 0.0024 & 1.8 & 13.1 \\
\hline
\end{tabular}

bold, no in vitro inhibition with MICs exceeding the highest value on E-test gradient strips: MIC $\geq 256 \mu \mathrm{g} / \mathrm{ml}$ for AMP, MIC $\geq 256$ $\mu \mathrm{g} / \mathrm{ml}$ for NAL, MIC $\geq 256 \mu \mathrm{g} / \mathrm{ml}$ for TET, MIC $\geq 32 \mu \mathrm{g} / \mathrm{ml}$ for TMP; \#, total biomass estimation (Hygiena, USA) *, relative to total microbial counts; ${ }^{* *}$, relative to bacterial counts grown at $20^{\circ} \mathrm{C} ; * * *$, relative to bacterial counts at $37^{\circ} \mathrm{C}$

Tab. 4: Antimicrobial resistance phenotype and percentage of E. coli isolates relative to cultivable bacteria in swabs.

\begin{tabular}{|lllcc|}
\hline Strain & Cave & Antimicrobial resistance phenotype & ATP (RLU) & E. coli (\%)* \\
\hline EC76 & Škocjanske jame & TET & 2,776 & 59.2 \\
EC77 & Škocjanske jame & TMP & 3,068 & 18.3 \\
EC78 & Škocjanske jame & AMP, TET, TMP & 3,068 & 18.3 \\
EC79 & Škocjanske jame & TET & 3,068 & 18.3 \\
EC85 & Škocjanske jame & AMP, CIP, NAL & 4,656 & 12.2 \\
EC86 & Škocjanske jame & TMP & 3,144 & 14.6 \\
EC110 & Postojnska jama & TMP & 26,456 & 8.6 \\
EC116 & Predjama & CHL & 3,468 & 4.7 \\
EC136 & Županova jama & AMP, CHL, NAL, TET & 1,720 & 0.6 \\
\hline
\end{tabular}

bold, no in vitro inhibition with MICs exceeding the highest value on E-test gradient strips: MIC $\geq 256 \mu \mathrm{g} / \mathrm{ml}$ for AMP, MIC $\geq 256$ $\mu \mathrm{g} / \mathrm{ml}$ for $\mathrm{CHL}, \mathrm{MIC} \geq 32 \mu \mathrm{g} / \mathrm{ml}$ for CIP, MIC $\geq 256 \mu \mathrm{g} / \mathrm{ml}$ for NAL, MIC $\geq 256 \mu \mathrm{g} / \mathrm{ml}$ for TET, MIC $\geq 32 \mu \mathrm{g} / \mathrm{ml}$ for TMP; relative to bacterial counts at $37^{\circ} \mathrm{C}$ 
Tab. 5: Antimicrobial resistance phenotype of E. coli isolates in guanos.

\begin{tabular}{|llcc|}
\hline Strain & Cave & Relative guano age & Antimicrobial resistance phenotype \\
\hline EC157 & Škocjanske jame & Non-fresh & TMP \\
EC163 & Škocjanske jame & Non-fresh & NAL \\
EC172 & Škocjanske jame & Non-fresh & CIP \\
EC201 & Škocjanske jame & Fresh & TMP \\
EC205 & Škocjanske jame & Fresh & TMP \\
\hline
\end{tabular}

Tab. 6: Susceptibility of E. coli from karst waters, surfaces and bat guano against six antimicrobials represented by MICs ( $n=168)$.

\begin{tabular}{|c|c|c|c|c|c|c|}
\hline & \multicolumn{6}{|c|}{$\mathrm{MIC}(\mu \mathrm{g} / \mathrm{ml})$} \\
\hline & AMP & $\mathrm{CHL}$ & $\mathrm{CIP}$ & NAL & TET & TMP \\
\hline Range & $0.5-256$ & $2-256$ & $0.008-32$ & $1.5-265$ & $0.75-265$ & $0.125-32$ \\
\hline Mean & 15.9 & 10.0 & 0.221 & 17.6 & 13.9 & 2.20 \\
\hline $\mathrm{MIC}_{50}$ & 4 & 8 & 0.016 & 6 & 2 & 0.5 \\
\hline $\mathrm{MIC}_{90}$ & 8 & 12 & 0.032 & 12 & 4 & 2 \\
\hline
\end{tabular}

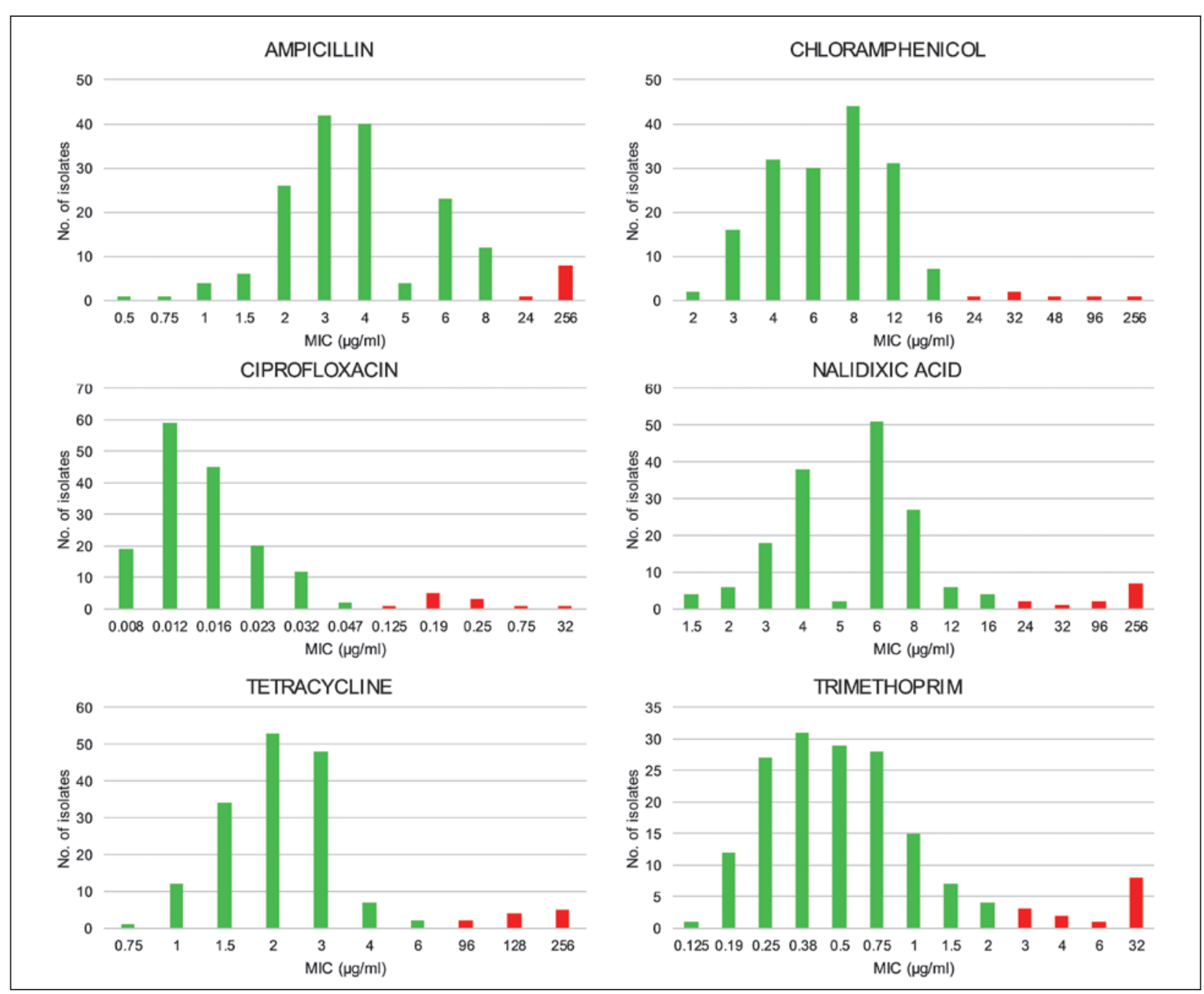

Fig. 3: MIC distributions for six antimicrobials. Green columns represent wild type MIC ranges; red columns represent non-wild type MIC ranges. 


\section{DISCUSSION}

Inevitably the global use of large quantities of antimicrobials to protect human and animal health, and to act as growth promotors, has led to the emergence and spread of $\mathrm{ARB}$ and ARG. In addition to compromising the treatment of infectious diseases, the natural resistome is constantly increasing in terms of the number and diversity of ARB and ARG. Pre-existing background levels of naturally occurring microbes, and those released due to discharge of human and animal waste, both contribute to the developing environmental resistome (Shao et al. 2018; Zhao et al. 2018).

This study was designed to assess the presence and number of total and AMR-E. coli compared to the total microbial biomass in samples from different sites in the Slovenian karst ecosystem. Since resistant E. coli strains allow the introduction of ARG into the natural resistome, from where they can again be mobilized into different strains and even species, tracking and identifying ARB and ARG in groundwater resources and their environment has become extremely important. Although the concentrations of antimicrobials and their metabolites in samples were not measured as part of the present study, their presence can be anticipated due to the the occurrence of AMR strains within the environment (Huang et al. 2011).

\section{ANTIMICROBIALS IN KARST HABITATS}

The presence in the environment of NWT E. coli strains resistant to AMP, CHL, CIP, NAL, TET and TMP has already been reported (Reinthaler et al. 2003; Amaya et al. 2012). Within the present study, resistance to at least one of the tested antimicrobials could be detected in 37 out of 168 E. coli isolates. Among these 23, 9 and 5 were from water, surface, and guano samples, respectively.

$\beta$-lactams, e.g., AMP, are the first and the most widely used group of antimicrobials, mainly because of their efficiency compared to their low toxicity (Pang et al. 2016), and thus the presence of resistance genes in natural ecosystems is to be expected. They are considered critically important by the World Health Organization (WHO) because of their wide use in treatment of infections caused by bacteria transmitted also from nonhuman sources or bacteria that acquire resistance genes from non-human sources (WHO 2017). Of 18 AMP-resistant strains, 6 were isolated from water, 3 from surfaces and none from the guano samples. $\beta$-lactam-resistant strains have previously been described in karst drinkingwater resources (Laroche et al. 2010).

The prevalance of NAL resistance was rather high in all screened habitats (Fig. 2). Eight out of eleven quinolone-resistant isolates were retrieved from water samples (Tabs. 3-5). NAL, the first synthetic quinolone, has been in clinical use since 1967 and historically was used to treat urinary-tract infections caused by Gram negative bacteria (Emmerson \& Jones 2003); nowadays it is used mostly as a screening test for (fluoro)quinolone resistance. The second generation fluoroquinolone, CIP, is one of the quinolones most prescribed in Europe (Van Doorslaer et al. 2011) and it is yet another critically important antimicrobial, especially in cases of invasive Campylobacter, Salmonella and multi-drug resistant Shigella infections. Quinolone-resistant infections can also result from a non-human source of Enterobacteriales, including E. coli (WHO 2017). Limited biodegradability of CIP in conventional wastewater treatment plants (Robinson et al. 2005; Grenni et al. 2018) might be the reason for the relatively high prevalence of associated resistance in karst waters (Fig. 2). Although resistance to both quinolones is due mainly to chromosomal mutations, horizontal transfer events of mutated chromosomal regions, mediated by phages, may play a significant role in AMR-resistance issues as recognized recently (Calero-Caceres et al. 2019; Balcazar 2020). Plasmid mediated quinolone resistance is also possible, and isolates like EC38, EC39 and EC27, with high MIC values for CIP and low MIC values for $\mathrm{NAD}$, are commonly resistant to quinolones due to plasmid transfer (Hooper \& Jacoby 2015).

Tetracyclines, which were the first antimicrobials used as growth promotors in the 1940s, are used predominantly in veterinary medicine (Speer et al. 1992; Chopra \& Roberts 2001). They are considered to be highly important antimicrobials because the loss of their efficacy, due to the emergence of resistance, would have a significant impact on morbidity and mortality, especially for infections caused by Brucella, Rickettsia and Chlamydia (WHO 2017). Among the 11 TET-resistant isolates met in this study, 7 were from water samples and 4 from surface samples. TET resistance genes are among the most commonly described from water samples, including those from the karst water supply (Chen et al. 2017; Stange \& Tiehm 2020).

TMP-resistant strains were the second most common AMR-E. coli encountered during the study. Among 13 isolates, 9 were from water samples, 4 from surfaces and, surprisingly, 3 from guano samples. TMP is an effective and cheap antimicrobial, commonly used in combination with sulfametoxazole to treat urinary-tract infections (Sköld 2001) with a relatively long half-life (when the maximum concentration is reduced to half maximum concentration) of 20 to 100 days in the environment (Zuccato et al. 2006; Grenni et al. 2018). TMP is 
considered an especially important antimicrobial, mainly because TMP-resistant infections can also originate from non-human sources (WHO 2017).

CHL is a broad-spectrum antibiotic. Its use in systemic therapy has been limited in many countries due to its toxicity, including apparent involvement in fatal occurrences of granulocytopaenia, aplastic anaemia and thrombocytopaenia (Berendsen et al. 2010; WHO 2017), but is still used mostly in veterinary medicine (Grenni et al. 2018). Whereas CHL-resistant E. coli strains are therefore not expected to be detected frequently, during this study 3 strains were isolated from water and 2 from surfaces (Tabs. 3-4).

Multiple drug-resistant strains were relatively common in rivers and on contact surfaces, but were not present in isolates from either fresh or old bat guano (Tabs. $3-5)$.

\section{AMR-E. COLI IN KARST WATER SYSTEMS}

AMR-E. coli strains were isolated from all the karst rivers except Črni potok, a small stream with a limited recharge area, that sinks into the Postojnski jamski sistem (Postojna Cave System). Of particular concern is the presence of resistant strains in samples from the Malenščica spring (Tab. 3), an important drinking-water source. Because the spring has an extensive recharge area it is difficult to pinpoint the exact faecal pollution point or points. Probable sources of AMR strains include agricultural runoff and wastewater effluents, although sewage treatment practices in the region have improved vastly in recent years. The prevalence of AMR-E. coli in the downstream underground flow is diminishing gradually, along with that of other microbial indicators (Tab. 3; Fig. 1). This can be attributed to a gradual die-off of bacteria along the underground course, but dilution with other waters within the karst aquifer cannot be excluded (Mulec et al. 2019). In addition, the successful dissemination of $E$. coli and other epidemiologically important microbes depends upon environmental factors. Favourable oxygen conditions support the viability of $E$. coli in water but, on the other hand, higher conductivity might have an adverse effect (Tab. 1). Low concentrations of antimicrobials can partly explain the higher prevalance of AMR-strains in waters.

\section{AMR-E. COLI ASSOCIATED WITH CONTACT SURFACES AND BATS IN CAVES}

It seems that cave conditions are not particularly adverse to microbial viability, due both to constant high humid- ity that prevents desiccation, and to the absence of UV irradiation. Tourists are probably the main source of AMR-strains on walking surfaces. They contribute significantly to the dissemination of resistant strains into and out of the cave and, in this respect, in spreading them to other ecosystems. A general low prevalence of E. coli in Postojnska jama can be attributed to regular cleaning of tourist footpaths and a disinfectant barrier at the tourist cave entrance. To a lesser extent the contamination of surfaces with ARB can also be attributed to water seepages. And, conversely, the use of water jets to clean surfaces in tourist caves might enhance the dispersion of ARB in the underground. The example of Postojnska jama demonstrates that those involved in tourist cave management should consider restricting the dispersion of microbial biomass on shoes by installing disinfectant barriers at cave entrances and exits (Appendix 2).

The third source of ARB in the karst ecosystem derives from different animals, including bats. Interestingly, more AMR-E. coli strains were isolated from surface swabs than from bat guano in Škocjanske jame, even though both sampling sites were in the same part of the cave. As migratory animals, bats can travel reasonable distances and contribute significantly to the spread of minute biological material. For example, in its annual seasonal migrations between winter and summer shelters $M$. schreibersii can fly more than 100 kilometres; the longest recorded distance is $833 \mathrm{~km}$ (Dietz \& Kiefer 2016). At least temporarily, the current presence of stable bat populations in Škocjanske jame and Predjama indicates the relatively favourable states of both habitats (Presetnik et al. 2017). Bats, particularly weakened ones, come into contact with different surfaces in caves, including tourist footpaths. AMR-strains that colonize these surfaces can enter the bat population. The inevitably close contacts between individual bats in the colonies ensure rapid spread of pathogens through the population. Hence, monitoring of bats should include regular follow-up of indicative microbial disease indicators, including those in fresh guano. Their complete health status and numerical presence provide perfect indications of environmental disturbances and wildlife conditions (Jones et al. 2009).

Whereas it is tempting to assume that bats are minor contributors to the overall ARB and ARG load within the karst ecosystem, additional studies are needed to help find out whether and to what extent E. coli strains from guano are disseminated through the karst. 


\section{CONCLUSIONS}

The karst ecosystem is extremely vulnerable with respect to microbial contamination from different sources. Being an important drinking water source and habitat for several rare and endangered species, it should be monitored for the presence of pathogenic and antimicrobial resistant bacteria, to detect and subsequently reduce or eliminate pollution sources.

Shoe-sole disinfection should be introduced at the entrances and exits of all tourist caves. Applied alongside restriction of tourist movements in parts of the cave that have recently been flooded and/or have heavy bat guano accumulations can cut down on the dissemination of bacteria among different habitats and potential hosts. Thus, the possibility of horizontal gene transfer of
ARG between pathogenic and environmental bacteria is reduced. More intermicrobial contacts can be made at underground sites with active water flow and significant air streaming, as well as along routes shared by migratory animals and humans.

Environmental conditions favouring the aquisition and maintainance of ARG, fitness costs and horizontal dispersal barriers, have not yet been studied in detail for E. coli. Further characterization of additional $E$. coli isolates from several sample sites is thus needed to help produce a broader picture on their pathogeneicity, mechanisms of antibiotic resistance, mobile genetic element content and transfer frequencies to other bacteria in karst habitats.

\section{ACKNOWLEDGEMENTS}

The authors acknowledge financial support from the Slovenian Research Agency (research core funding no. P6-0119 and project "Environmental effects and karst water sources: impacts, vulnerability and adaptation of land use", no. J6-8266). Public Service Agency Škocjan Caves Park and Postojnska jama are thanked for providing additional financial and logistical support. The project "Development of research infrastructure for the international competitiveness of the Slovenian RRI space - RI-SI-LifeWatch" co-financed by the Republic of Slovenia, Ministry of Education, Science and Sport and the European Union from the European Regional Development Fund enabled some extra environmetal analyses. The authors also acknowledge David Lowe for providing language-editing assistance.

\section{REFERENCES}

Amaya, E., Reyes, D., Paniagua, M., Calderon, S., Rashid, M., Colque, P., Kuhn, I., Mollby, R., Weintraub, A. \& C. Nord, 2012: Antibiotic resistance patterns of Escherichia coli isolates from different aquatic environmental sources in León, Nicaragua.- Clinical Microbiology and Infection, 18, 9, E347-E354. https://doi.org/10.1111/j.1469-0691.2012.03930.x

ARSO, 2019: Slovenian Environment Agency, Lidar data fishnet.- [Online] Available from: http://gis.arso. gov.si/ [Accessed 9th May 2019].

Balcázar, J.L., 2020: Implications of bacteriophages on the acquisition and spread of antibiotic resistance in the environment.- International Microbiology, 23, 475479. https://doi.org/10.1007/s10123-020-00121-5

Berendsen, B., Stolker, L., De Jong, J., Nielen, M., Tserendorj, E., Sodnomdarjaa, R., Cannavan, A. \& C. Elliott, 2010: Evidence of natural occurrence of the banned antibiotic chloramphenicol in herbs and grass.- Analytical and Bioanalytical Chemistry, 397, 1955-1963. https://doi.org/ 10.1007/s00216-010-3724-6

Calero-Cáceres, W., Ye, M. \& J.L. Balcázar, 2019: Bacteriophages as environmental reservoirs of antibiotic resistance.- Trends in Microbiology, 27, 7, 570-577. https://doi.org/10.1016/j.tim.2019.02.008

Cave Cadastre, 2019: Cave Register of the Karst Research Institute ZRC SAZU and Speleological Association of Slovenia. Postojna, Ljubljana.

Chen, Z., Yu, D., He, S., Ye, H., Zhang, L., Wen, Y., Zhang, W., Shu, L. \& S. Chen, 2017: Prevalence of antibiotic-resistant Escherichia coli in drinking water sources in Hangzhou City.- Frontiers in Microbiology, 8, 1133. https://doi.org/10.3389/fmicb.2017.01133

Chopra, I. \& M. Roberts, 2001: Tetracycline antibiotics: Mode of action, applications, molecular biology, and 
epidemiology of bacterial resistance.- Microbiology and Molecular Biology Reviews, 65, 2, 232-260. https://doi.org/10.1128/MMBR.65.2.232-260.2001

Dietz, C. \& A. Kiefer, 2016: Bats of Britain and Europe.Bloomsbury Publishing, pp. 398, London.

Emmerson, A. \& A. Jones, 2003: The quinolones: decades of development and use.- Journal of Antimicrobial Chemotherapy, 51, S1, 13-20. https://doi. org/10.1093/jac/dkg208

European Committee on Antimicrobial Susceptibility Testing, 2017: Standard operating procedure: MIC distributions and the setting of epidemiological cutoff (ECOFF) values, EUCAST SOP: 10.0.- [Online] Available from: https://www.eucast.org/fileadmin/ src/media/PDFs/EUCAST_files/EUCAST_SOPs/ EUCAST_SOP_10.0_MIC_distributions_and_ epidemiological_cut-off_value_ECOFF__setting_20171117.pdf [Accessed 26th April 2019].

European Centre for Disease Prevention and Control, 2018: Surveillance of antimicrobial resistance in Europe: annual report of the European Antimicrobial Resistance Surveillance Network (EARS-Net) 2017.- [Online] Available from: https://www.ecdc. europa.eu/sites/default/files/documents/AMR\%20 2017_Cover\%2BInner-web_v3.pdf [Accessed 26th April 2019].

European Centre for Disease Prevention and Control, 2019: Surveillance of antimicrobial resistance in Europe: annual report of the European Antimicrobial Resistance Surveillance Network (EARS-Net) 2018.- [Online] Available from: https://www.ecdc. europa.eu/sites/default/files/documents/surveillance-antimicrobial-resistance-Europe-2018.pdf [Accessed 20th December 2019].

European Committee on Antimicrobial Susceptibility Testing, 2019: MIC and zone diameter distributions and ECOFFs.- [Online] Available from: http://www. eucast.org/mic_distributions_and_ecoffs/ [Accessed 26th April 2019].

Grenni, P., Ancona, V. \& A. Barra-Caracciolo, 2018: Ecological effects of antibiotics on natural ecosystems: A review.- Microchemical Journal, 136, 25-39. https://doi.org/10.1016/j.microc.2017.02.006

Hooper, D.C. \& G.A. Jacoby, 2015: Mechanisms of drug resistance: quinolone resistance.- Annals of the New York Academy of Sciences, 1354, 1, 12-31. https:// doi.org/10.1111/nyas. 12830

Huang, C., Renew, J., Smeby, K., Pinkston, K. \& D. Sedlak, 2011: Assessment of potential antibiotic contaminants in water and preliminary occurrence analysis.- Journal of Contemporary Water Research and Education, 120, 4. https://doi. org/10.1142/9789812799555_0004
Jang, J., Hur, H.G., Sadowsky, M.J., Byappanahalli, M.N., Yan, T. \& S. Ishii, 2017: Environmental Escherichia coli: ecology and public health implications-a review.- Journal of Applied Microbiology, 123, 3, 570581. https://doi.org/ 10.1111/jam.13468

Jones, G., Jacobs, D.S., Kunz, T.H., Willig, M.R. \& P.A. Racey, 2009: Carpe noctem: the importance of bats as bioindicators.- Endangered Species Research, 8, 1-2, 93-115. https://doi.org/10.3354/esr00182

Kačaroğlu, F., 1999: Review of groundwater pollution and protection in karst areas.- Water Air and Soil Pollution, 113, 337-356.

Laroche, E., Petit, F., Fournier, M. \& B. Pawlak, 2010: Transport of antibiotic-resistant Escherichia coli in a public rural karst water supply.- Journal of Hydrology, 392, 1-2, 12-21. https://doi.org/10.1016/j. jhydrol.2010.07.022

Mulec, J., Petrič, M., Kozelj, A., Brun, C., Batagelj, E., Hladnik, A. \& L. Holko, 2019: A multiparameter analysis of environmental gradients related to hydrological conditions in a binary karst system (underground course of the Pivka River, Slovenia).- Acta Carsologica, 48, 3, 313-327. https://doi. org/10.3986/ac.v48i3.7145

Mösslacher, F., Griebler, C. \& J. Notenboom, 2001: Biomonitoring of groundwater systems: methods, applications and possible indicators among the groundwater biota.- In: Griebler, C. et al. (eds.) Groundwater ecology: A tool for management of water resources. Office for Official Publications of the European Communities, pp. 132-170, Luxembourg. Notenboom, J., Plénet, S. \& M.J. Turquin, 1994: Groundwater contamination and its impact on groundwater animals and ecosystems.- In: Gibert, J. et al. (eds.) Groundwater ecology. Elsevier, pp. 477-504, London.

Odonkor, S.T. \& J.K. Ampofo, 2013: Escherichia coli as an indicator of bacteriological quality of water: an overview.- Microbiology Research, 4,1, e2-e2. https://doi.org/10.4081/mr.2013.e2

Pang, Y., Huang, J., Xi, J., Hu, H. \& Y. Zhu, 2016: Effect of ultraviolet irradiation and chlorination on ampicillin-resistant Escherichia coli and its ampicillin resistance gene.- Frontiers of Environmental Science \& Engineering, 10, 3, 522-530. https://doi.org/ 10.1007/s11783-015-0779-9

Petrič, M., 2010: Case study: Characterization, exploitation, and protection of the Malenščica karst spring, Slovenia.- In: Krešić, N. \& Z. Stevanović (eds.) Groundwater Hydrology of Springs: Engineering, Theory, Management and Sustainability. Elsevier, Butterworth-Heinemann, pp. 428-441, Burlington. https://doi.org/10.1016/B978-1-85617-5029.00012-8 
Presetnik, P., Koselj, K., Zagmajster, M., Zupančič, N., Jazbec, K., Žibrat, U., Petrinjak, A. \& A. Hudoklin, 2009: Atlas netopirjev (Chiroptera) Slovenije.- Center za kartografijo favne in flore, pp. 152, Miklavž na Dravskem polju.

Presetnik, P., Šturm, S., Debevec, V. \& T. Zorman, 2017: Netopirji v Parku Škocjanske jame.- Park Škocjanske jame, pp. 163, Škocjan.

Reinthaler, F.F., Posch, J., Feierl, G., Wüst, G., Haas, D., Ruckenbauer, G., Mascher, F. \& E. Marth, 2003: Antibiotic resistance of $E$. coli in sewage and sludge.Water Research, 37, 8, 1685-1690. https://doi.org/ 10.1016/S0043-1354(02)00569-9

Robinson, A.A., Belden, J.B. \& M.J. Lydy, 2005: Toxicity of fluoroquinolone antibiotics to aquatic organisms.- Environmental Toxicology and Chemistry, 24, 2, 423-430. https://doi.org/10.1897/04-210R.1

Shao, S., Hu, Y., Cheng, J. \& Y. Chen, 2018: Research progress on distribution, migration, transformation of antibiotics and antibiotic resistance genes (ARGs) in aquatic environment.- Critical Reviews in Biotechnology, 38, 8, 1195-1208. https://doi.org/10.10 80/07388551.2018.1471038

Sköld, O., 2001: Resistance to trimethoprim and sulfonamides.- Veterinary Research, 32, 3-4, 261-273. https://doi.org/10.1051/vetres:2001123

Speer, B.S., Shoemaker, N.B. \& A.A. Salyers, 1992: Bacterial resistance to tetracycline - mechanisms, transfer, and clinical significance.- Clinical Microbiology Reviews, 5, 4, 387-399. https://doi.org/10.1128/ cmr.5.4.387

Stange, C. \& A. Tiehm, 2020: Occurrence of antibiotic resistance genes and microbial source tracking markers in the water of a karst spring in Germany.Science of The Total Environment, 742, 10, 140529. https://doi.org/10.1016/j.scitotenv.2020.140529
Van Doorslaer, X., Demeestere, K., Heynderickx, P.M., Van Langenhove, H. \& J. Dewulf, 2011: UV-A and UV-C induced photolytic and photocatalytic degradation of aqueous ciprofloxacin and moxifloxacin: Reaction kinetics and role of adsorption.- Applied Catalysis B: Environmental, 101, 3-4, 540-547. https://doi.org/10.1016/j.apcatb.2010.10.027

Vitousek, P.M., Mooney, H.A., Lubchenco, J. \& J.M. Melillo, 1997: Human domination of Earth's ecosystems.- Science, 277, 5325, 494-499. https://doi. org/10.1126/science.277.5325.494

World Health Organization, 2017: Critically important antimicrobials for human medicine: ranking of antimicrobial agents for risk management of antimicrobial resistance due to non-human use.- World Health Organization , $5^{\text {th }}$ revision. Licence: CC BY-NC-SA 3.0 IGO.

Zhang, P., Xu, P., Xia, Z., Wang, J., Xiong, J. \& Y. Li, 2013: Combined treatment with the antibiotics kanamycin and streptomycin promotes the conjugation of Escherichia coli.- FEMS Microbiology Letters, 348, 2, 149-156. https://doi.org/10.1111/1574-6968.12282

Zhao, Y., Ye, L. \& X. Zhang, 2018: Emerging PollutantsPart I: Occurrence, Fate and Transport.- Water Environment Research, 90, 10, 1301-1322. https://doi. org/10.2175/106143018X15289915807236

Zuccato, E., Castiglioni, S., Fanelli, R., Reitano, G., Bagnati, R., Chiabrando, C., Pomati, F., Rossetti, C. \& D. Calamari, 2006: Pharmaceuticals in the environment in Italy: causes, occurrence, effects and control.- Environmental Science and Pollution Research, 13, 1, 15-21. http://dx.doi.org/10.1065/ espr2006.01.004 


\section{APPENDIX}

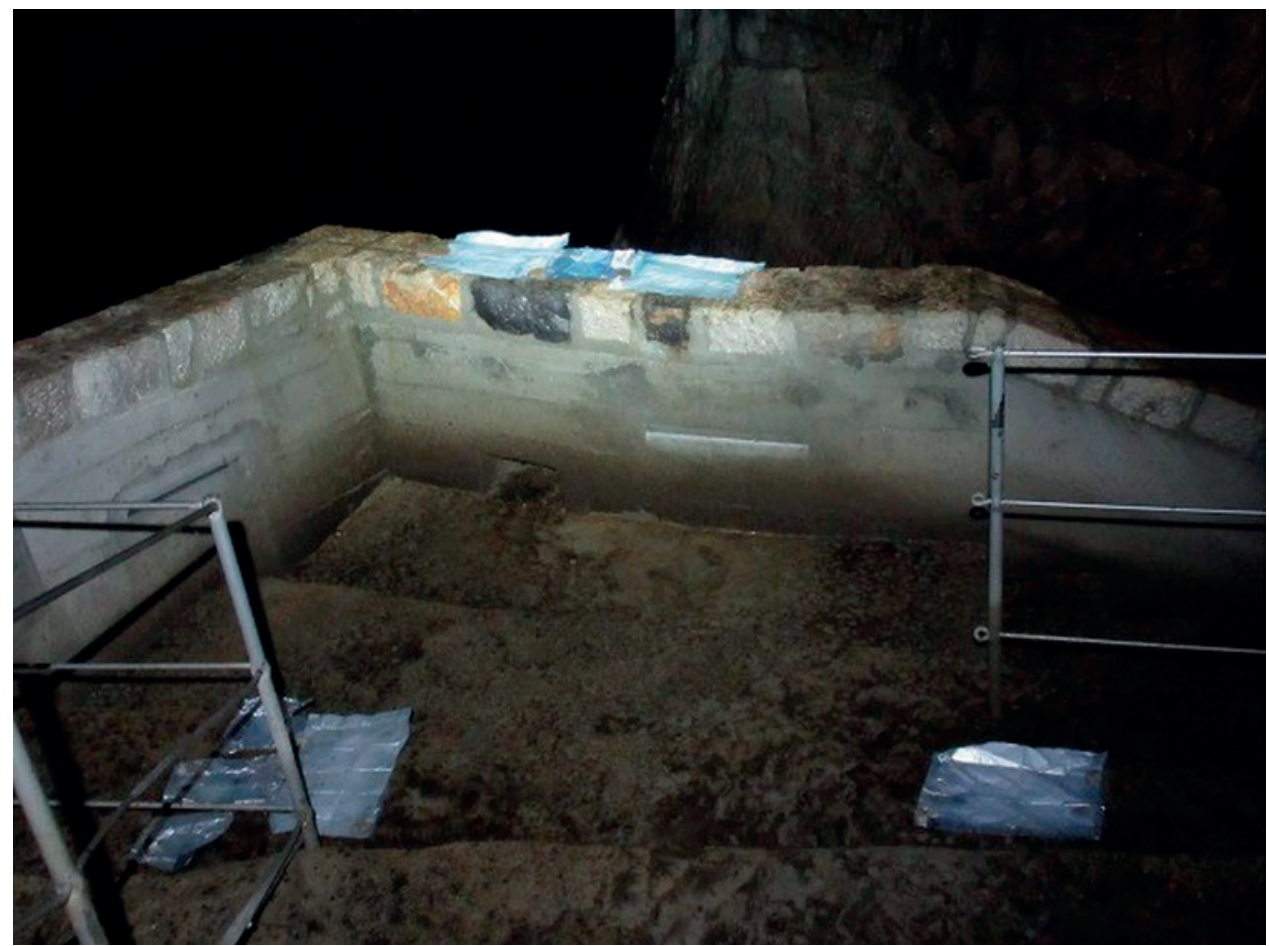

Appendix 1: Collection of fresh guano on a sterile aluminium foil placed under colonies of roosting bats along the tourist footpath in Škocjanske jame, Rudolfova dvorana (Photo: S. Šturm).

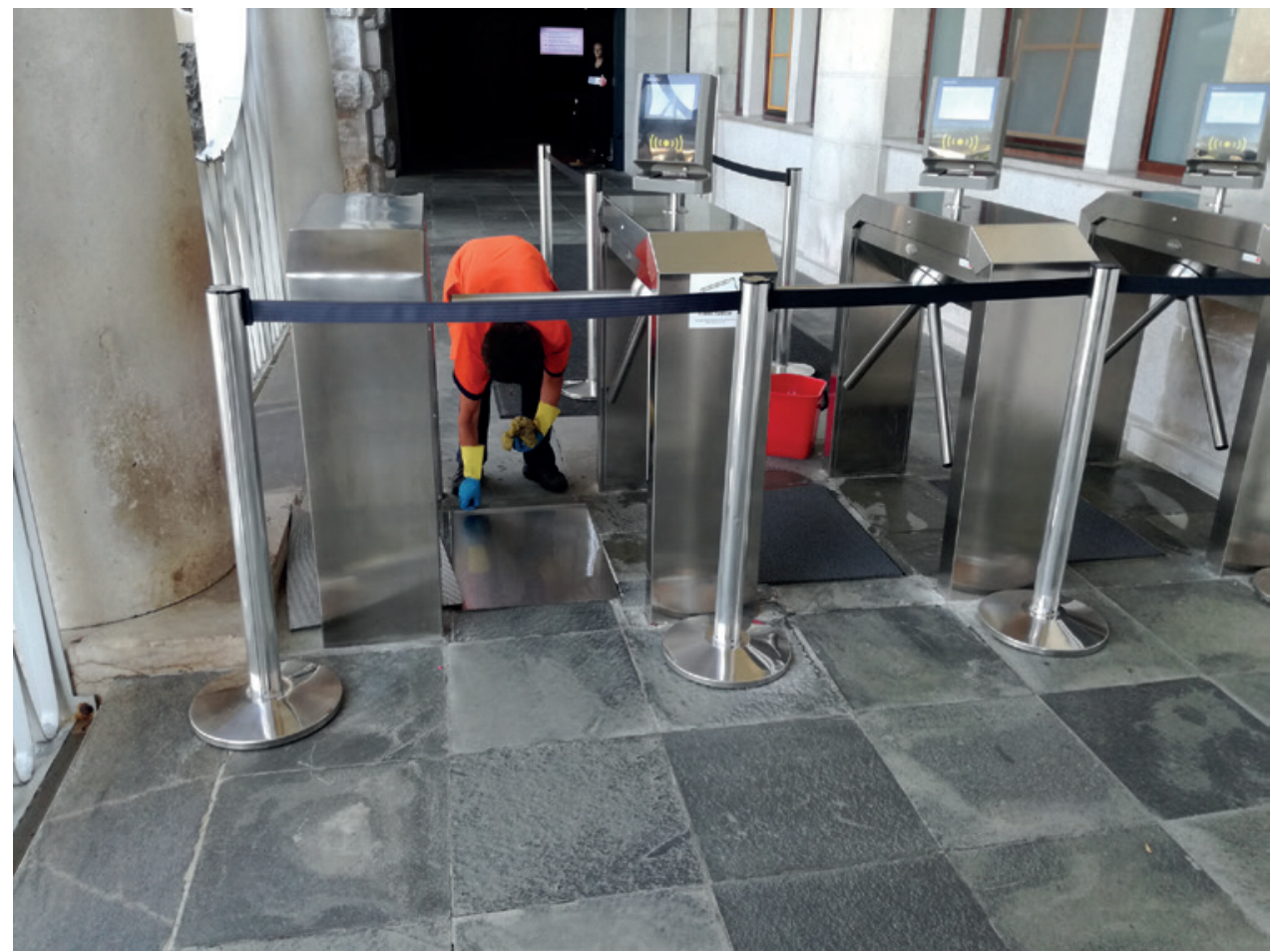

Appendix 2: Disinfectant barrier at the entrance to Postojnska jama (Photo: J. Mulec). 